\title{
THE DESIGN \& DELIVERY OF QUALITY SERVICES: A PARADIGM SHIFT
}

\author{
DBH Smith (Private practice)
}

As result of the increasingly important role information technology (IT) is playing in service provision, less person-to-person contact will in future be made during service provision. Highly skilled specialists will make the remaining contact. Emphasis will shift to speed of delivery, with logistics playing an important role. The designers of services must take these factors into account if they wish to design quality services.

Key words: consumer behaviour, Total Quality Service, service delivery, service management, servtech model, servuction service model, quality services

\section{INTRODUCTION}

\section{Service is becoming increasingly important}

There can be no doubt that the service component of modern economies is becoming increasingly important. Great emphasis has in the past been placed on the interaction between suppliers of services and customers during the delivery process of services. A question which is going to be increasingly asked, is whether this element is going to be as important in the future. The advent of modern Information Technology (IT) systems is leading to decreased interactions between staff and customers and in the future more emphasis will have to be placed on logistic support because delivery mechanisms are going to change. Increasing focus will in future have to be placed on integrating IT and logistics into Total Quality Service (TQS). The challenges facing management are going to be increasingly volatile, which will make it all the more important for managers not to "talk" TQS but to "live" it, and to rapidly change systems and procedures to meet rapidly changing circumstances. In this paper, attention is given to the changing face of services and the challenges it poses to management.

Economic growth in the last quarter of the $20^{\text {th }}$ century has fuelled the growth of the service industry. The result has been a phenomenal growth in service industries in the late $20^{\text {th }}$ century. All the developed economies today have large service sectors and many firms today, particularly in the IT and financial services field, export services to countries throughout the world.

While services grew, manufacturing declined. In 1970, manufacturing accounted for $26 \%$ of American gross domestic product (GDP), but in 1991, it only accounted for $21 \%$. In Germany manufacturing as a percentage of GDP fell from $41 \%$ in 1970 to $28 \%$ in 1991. In Japan the figures showed a drop from 36\% to 29\% (Bateson 1995:5). As the service industry grew, it absorbed some of the jobs shed by traditional industries such as agriculture, mining and manufacturing. 
In reality, services is a greater percentage of GDP than statistics show, the reason being that many goods producing companies have, within their structure, a large service component.

\section{The human element of services}

Services are in most cases provided by humans. It is therefore only logical that the human face of service provision is important. Human capital is replacing physical capital as an important source of investment.

Other than manufacturing organisations where machines do most of the jobs, in the service economy people are the machines that produce wealth. For this reason the service organisations of the $21^{\text {st }}$ century will have to invest huge amounts of capital in the skills of their people. The types of skills required are, with the huge impact of IT, going to change rapidly and may very well change more to IT based skills, web design and logistics than the historically accepted personal interface skills associated with service provision.

\section{THE CHALLENGES FACING SERVICE ORGANISATIONS}

\section{Become more customer oriented}

The challenge facing many organisations is how they can become more customeroriented. Central to customer orientation is meeting customer needs. Management must adopt new ways of thinking and it must take action, based on the principles of service management. Management must package in-time information services, with tangible attributes (i.e. a consumer benefit package must be offered). By doing this the organisation can gain competitive advantage. Quality management practises must therefore become an accepted part of the life of the service organisation.

Management achieves these practises by:

- providing clear leadership at the top and at all levels in an organisation

- integrating all activities for effective planning and deployment processes

- collecting, analysing and using data for control and improvement

- creatively involving all people in an organisation

- focusing on the understanding of customer needs and expectations as well as customers' perceptions of performance and

- controlling and continuously improving processes in the total management system to achieve this.

In the case of a service organisation service rendering normally fails at the interface between the customer and the service provider. Management must therefore place emphasis on doing the right things right. This can only be done if a management system is developed which places emphasis on training staff on what is right, how things must be done right and managing human interactions.

\section{Manage human interactions}


Those rendering the service are, in most cases, expected to render an excellent service and they are often caught between the organisation on the one hand and the customer on the other hand. They are expected to cope with all the ensuing conflicts which result from this contact. Service jobs, therefore, have in many cases extremely high staff turnovers. The cost of hiring and training new sales assistants, cashiers and other service providers are in many cases very high, and for this reason, service rendering requires from management, not only proper design of the services, but also the management of contact personnel.

\section{Provide customer benefits}

Products, whether they are goods or services, normally deliver a bundle of benefits to the consumer. For this reason the so-called benefit concept has become important in most articles and books dealing with marketing. The consumer, when he/she purchases a product/service, in fact, purchases an experience which is created by that particular product or service. The customer wishes this experience to be beneficial to him/her and the product or service therefore delivers a bundle of benefits to he consumer, through the experiences of the consumer.

In the case of goods, this benefit package normally comes together with the actual goods delivered and is lost once the goods or products are consumed or used. In the case of services, however, these benefits can come from a number of sources at the same time.

\section{The Servuction Model}

The benefit concept has lead to the development of the servuction service model of Langeard \& Eglier (Langeard et al. 1981: 81-104). In this model the service is broken into two parts, namely:

- that which is visible to the consumer and

- that which is invisible to the consumer.

Obviously the visible part of the organisation will be influenced by the invisible part. Similarly the invisible design part of a quality management system will influence the visible rendering of the services.

The visible part of the organisation is broken down into two parts, namely:

- the physical environment in which the service is rendered; and

- the contact personnel rendering the service.

The model suggests that customer $A$, who is purchasing the service, can also be effected by customer $B$, who may be in contact with the service organisation at the same time. The benefits package, therefore, is derived from an interactive process of experiences. The visible components of the organisation are supported by the invisible components that provide the administration and maintenance of the physical facilities and at the same time, because services are often delivered to groups of customers, 
benefits are derived from interaction with other customers. The whole of the servuction system creates the experience, and the experience, in turn, creates the benefit to the consumer.

\section{The current and changing implications of the servuction model}

Bateson (1995:11-17) lists a number of conclusions, resulting from the servuction service model that are of direct importance to the problems of service marketing.

\section{Services cannot be inventoried}

The general consensus in the past was that services cannot be inventoried because they are produced and consumed at the same time, i.e. the consumer is part of the system. This is still true in many cases, but is no longer a universal truth. An air flight ticket can now be purchased via the Internet. In the purchase transaction, interaction between the client and the service provider personnel is eliminated. The Internet is "storing" the service and it is then consumed. However, there is then a further element with consumption and production occurring simultaneously. The person buying the air ticket will fly and the in-flight service will be produced and consumed during the flight.

Service provision such as auction services, vehicle sales and many others via the Internet will, in future, become an accepted way of life, and the service deliverer will inventory these items via IT, and will make them available via the Internet.

\section{Services are time dependent}

Historically it was assumed that services cannot be planned ahead. For example, motor vehicle owners need a service such as that provided by the AA, which must be delivered when asked for. Obviously, this still applies today. But this can change. Maintenance plans for vehicles in which equipment and vehicles must be maintained according to a predetermined set of rules and standards, will become more the norm than the exception. The more these types of plans are implemented, the less the likelihood there may be for "on demand" services.

\section{Services are place dependent}

As recent as the late 1990s the place where the service experience took place was largely dependent on the consumer. With the advent of the Internet, this is no longer necessarily the case. The service organisation can now use the Internet to provide the service instead of having a large number of locations.

\section{Consumers are always involved in the "factory"}

It was historically believed that consumers are always an integral part of the service process and that their participation may be either active or passive but that their role cannot be ignored. It was therefore believed (Bateson 1995:14-15) that:

- if the "factory" was changed, consumer behaviour had to change as well

- if the benefit concept was changed, the "factory" had to change 
- everyone who comes into contact with the consumer is delivering the service

- everything that comes into contact with the consumers, is delivering the service.

This statement can no longer be accepted in toto. The behaviour of the consumer may in future very well be based on the technology, which is available to the consumer more than the change in the factory (the consumers may not even be aware of changes in the factory). The factory will place more importance on the logistics to get the service to the consumer after initial contact between consumer and the factory. The relationship between the consumer and the factory will become more impersonal and they will, in fact, be separated from each other.

\section{Changes in the "factory" means changes in consumer behaviour}

It is still true that the changes, which are made to the visible part of, the service firm and which are apparent to the consumer, may affect his/her decision-making and purchase processes. In future, aspects such as web page design, accessibility to web pages, information contained in web pages and ease of movement within web pages, may very well influence consumer behaviour and alter their behaviour. Modern first world economies are on an IT roller coaster.

Younger generations are changing their behaviour and are becoming IT friendly. The modern service provider cannot ignored the proliferation in e-commerce activities and Internet applications. These have huge implications on the historically developed service delivery models. As the pressure to use technology builds up, consumer behaviour will change further. It will no longer be a question of voluntary change, but forced change because of circumstances rather than free will.

\section{Changes in the benefit concept means changes in the "factory"}

Obviously, this still holds true. If the package of benefits offered to clients change, it means that the service provider must change its specifications for service design and service offerings. These changes may not always be obvious to the consumer who may only see the final service. In many cases, the customer will still be involved in the factory (i.e. where the service is rendered).

Typical examples are hairdressers where the customer is part of the production process. But again, the design of the service may become more important. There are already computerised programmes showing people exactly how they will look with a specific type of hairstyle, before the hairdresser actually cuts their hair. This design is part of the invisible service to the customer, but may very well affect the customer's behaviour. The service organisation will therefore have to harness its power to influence decision-making processes of the customer.

Everyone and everything that comes into contact with the consumer is delivering the service 
Historically there were many contact points between customers and personnel of organisations (e.g. telephonists, enquiry clerks, couriers, cashiers, were all part of the contact process). In future the personal contact points will diminish rather than increase. More enquiries will be made via IT and less through direct contact. This will mean a re-think on personnel planning in service organisations as well as the type of training required for staff.

\section{Contact people are products}

Historically, customers were part of the service delivery process and so were contact personnel. This still holds true in many cases. Contact personnel are not objects. Because they are human, they exhibit variances that cannot be controlled by the service process. This is a reality that the service provider must take into account.

The importance of contact may, however, in future, diminish. The contact between customer and organisation will often be more impersonal. To ensure a competitive advantage the contact which is delivered, via IT or otherwise, must be so good that the customer will wish to purchase a particular service or product.

\section{Services cannot be quality controlled at the "factory gate"}

One of the greatest problems historically in the service industry is the fact that consumption and production often occurs as the same time. The service organisation finds it extremely difficult to control staff behaviour. If something goes wrong during service provision, it is virtually impossible for the service provider to institute quality control. It is therefore, by definition, virtually impossible for a service to achieve $100 \%$ perfect quality on an ongoing basis, because of the human element that forms part of the production of the service. However, as technology develops and as less reliance is placed on the interface interaction between personnel and customers, the challenge to the service provider will be to increase the chance of $100 \%$ service delivery.

\section{THE SERVICE ORGANISATION OF THE FUTURE}

\section{Developing a new model}

As pointed out, IT is going to have profound effects on the service organisation of the future. The challenge for organisations will therefore be to combine personal contact with IT and ecommerce and to promote logistical support systems that can meet customer expectations.

While the pure servuction service mode/ will still apply to those cases where production and consumption of the service occur at the same, it will increasingly be substituted or complemented by the servtech model. Customers may act in isolation of each other and the service provider, but will be influenced by technology. Personal relationships will be vitally important in the limited cases where personal contact is made. 
The visible part of the service will be more IT based. The interaction with other customers will be limited to the extent by which they affect the service provided to other customers (i.e. too many users using the same site at the same time). The implications of the servtech model on service organisations are immense. Big investments will have to be made in IT and the design of systems to ensure that the ultimate service is properly delivered, including more emphasis on training of IT specialists and bigger investments in hardware and software. Contact personnel will have to be highly trained. Call centre operators will, for example, have to be organisational specialists who will have to be able to provide immediate information on virtually all aspects of the organisation to customers. Increased attention will have to be given to logistical design. The customer will, once a service or product is purchased, insist on speedy delivery. The design process will have to take this into account.

There is an increasing awareness that growth of IT and e-commerce will have profound implications for service delivery. According to Beeld (2000:6), e-commerce will increase in value from R2,289 billion in 1998 to between R10 500 and R14 000 billion in 2003. According to the article speakers at the $37^{\text {th }}$ Congress of the International Advertising Agency, however, emphasised that notwithstanding this phenomenal growth, the value of personal contact must never be underestimated. Because reputation, relationships and image cannot be easily duplicated (as is the case with $e$ commerce services) these will become increasingly valuable and will become the foundation of the new economy.

\section{Changing the service profit chain}

The ultimate aim of any organisation is to improve profitability. It is a fact that one of the best ways to improve profitability is to provide a better service to customers than competitors. However, changes in technology will affect the steps service organisations must take to achieve maximum profitability. Successful service managers pay attention to the factors that drive profitability in this new service paradigm: investment in people, technology that supports front line workers, revamped recruiting and training practises and compensation linked to performance for employees at every level. The crux of the argument is that the new economics of service will require innovative measurement techniques. These techniques will calibrate the impact of employee satisfaction, loyalty and productivity on the value of products and services delivered so that managers can build customer satisfaction and loyalty and assess the corresponding impact on profitability and growth. The aim of a good service profit chain is therefore to increase revenue growth and profitability.

\section{The current service profit chain}

Heskett et al. 1994: 165-174 developed the service profit chain. The proposition is that revenue growth is a chain achieved through customer loyalty which is a direct result of customer satisfaction which, in turn, is influenced by the services provided to the customer. Value is created by satisfied, loyal and productive employees. Employee satisfaction in turn depends on good internal, high quality, support services which enable employees to deliver results to customers. 


\section{The future service profit chain}

Although the Hesketts service profit chain is only six years old rapid changes in technology means that it will have to adapt to cope with changing circumstances. With the growth of advanced IT applications, it is going to become increasingly easier for the customer to scan "the web" and to evaluate the offerings of services on the web page. Customer loyalty in future is going to become increasingly difficult to maintain and service organisations will have to take this into account in their planning. Strenuous efforts will have to be made to retain customers through:

- highly trained specialists who will have to use limited personal contact opportunities with customers, to maximum effect;

- sophisticated IT systems which will enable customers to access information as quickly as possible; and

- logistic support systems to ensure that purchased products/services reach customers as quickly as possible.

The service profit chain of the $21^{\text {st }}$ century must take such realities into account.

The $21^{\text {st }}$ century service profit chain differs from the historical service profit chain, in that customer satisfaction will now depend on a large number of aspects which were not included in the previous models. Many organisations will be offering virtually the same services which may lead to customer satisfaction and organisations will have to seek something special. Even though a good service may be provided and the customer perceives the service to be good, the customer will have many choices available through the use of IT.

In essence the $21^{\text {st }}$ Century service profit chain will work as follows:

- Revenue growth will, as in the past, be influenced by customer loyalty which will be the direct result of customer satisfaction.

- Customer satisfaction will, however, be influenced by service offerings such as web page design, availability of high speed acces s, linkages with service providers, download abilities of software, easy customising of software downloaded to customers, and the supplier of services linking his services efficiently and effectively with support service providers such as high speed delivery of products. Logistics design to improve high speed delivery is going to become vitally important. At the same time personal contact will have to be of the highest standards.

- External service value (e.g. the quality of the product or service including delivery time) will be created by loyal, productive, adaptable and high integrity staff. Organisations will have to retain highly trained staff.

- Internal quality will drive employee satisfaction. The quality of the internal services, such as the availability and upgrading of IT hardware and software, the freedom of employees to make decisions within their jobs, employee empowerment, employee recognition and reward systems, proper selection of 
employees in which merit should be the most important factor, development of employees through continuous training, making tools available to employees to improve service to customers and workplace design, will all drive employee satisfaction.

\section{Leadership and the profit chain}

Underpinning the $21^{\text {st }}$ Century profit chain is good leadership. The service organisation of the $21^{\text {st }}$ century is going to face the reality that:

- services are going to be rendered in a highly competitive world where entry levels for new competitors might be relatively low because of increased affordability of IT

- services are going to be rendered in an impersonal world where contact with the customer might be drastically reduced

- the service organisation of the future will work within a more impersonal customer/organisational relationship and will have to place increased emphasis on adding value through the better utilisation of information, combining this with improved service delivery through better use of sub-contractors, including subcontractors which come in direct contact with the customer and using highly trained and professional personnel in contact situations

- staff within the service organisation will have to focus totally on customer satisfaction, but without necessarily having direct contact with the customer. This turns the historic concept of what is required from service staff on its head in that increasing numbers of staff within the service organisation might have limited contact with customers. They must, however, remain customer-focused. In this process management might feel that because they are working in an increasingly impersonal environment they may distance them from their customers. This will be a grave mistake. Management will have to realise that customer satisfaction will have to be achieved through a combination of IT, e-commerce, logistics and highly effective and professional contact. The core value system of the organisation, namely satisfying its internal and external customers through a deep-rooted quality belief system, is going to become increasingly important as the organisation, through the use of technology, can in fact, grow nearer to its customer base, and may use non-interface contacts as a method to grow relationships.

Core values will become increasingly important because integrity and honesty in the design process, in the commitment to customers, in the commitment of staff, in the strive towards quality, might be the one factor which distinguishes one organisation from the other.

\section{RETAINING CUSTOMERS}

Customer retention is going to be vitally important for $21^{\text {st }}$ Century organisations. With the advance of IT, customer choices are going to increase dramatically. Organisations will therefore have to take active steps to reduce defections. It has been proved that it costs up to three to five times less to keep customers than to get new ones (Bateson 
1995:457). First world populations are becoming increasingly stagnant and there are less new customers to go around.

To retain customers organisations will have to:

- Adopt strategies to reduce customer defections by managing defections. Systematic process that actively attempt to retain customer before they defect will have to be developed;

- Develop customer retention plans. To achieve this retention strategies will have to be developed

- Place the customer in the centre

- Take steps to understand customer behaviour

- The gap between management perceptions and customer expectations

- Understand all factors which influence service quality evaluation by the customers

- Accept that adequate service will no longer suffer but that exceptional services will have to be offered

- Take active steps to improve service quality

- Design of services will have to incorporate retention strategies

\section{THE FUTURE ROLE OF LOGISTICS}

Logistics is going to become one of the most important parts of service delivery. Where in the past much attention was given to controlling the interaction between customer and service provider or manufacturer, the future service will focus more on how to get the service or product to the customer as quickly as possible. With the advent of IT, distance will become largely irrelevant as the purchaser of a product or a service will purchase the product from a place that may literally be thousands of kilometres away from his or her location. However, the purchaser will expect the product to be delivered to him/her as quickly as possible.

More time will have to be spent by organisations on finding ways to get the product to the consumer as quickly as possible. Until now, this has been a largely untouched part of service discussions but commentators and writers are starting to recognise the substantial implications of this process. An interesting quote is that of Pitendrigh (Sakebeeld, 27 May:1) "Waar vernuf gaan nodig wees, is nie in die bou van webwerwe nie, maar in die toepassing van die besigheid-tot-besigheid (B2B) logistiek wat met die uitvoer van bestellings, beskikbaarheid van voorrade en betalings gepaard gaan."

Inventory management is going to become vitally important and rapid movement of stock will effect where warehouses must be situated, how stock can move out of those warehouses to destinations as quickly as possible and what contractors must be used. The organisation will face the reality that it might not be able to forecast demand for products and stock as accurately as in the past and will therefore have to put logistic measures in place to ensure that products / services are assembled and supplied, virtually on demand. 


\section{CONCLUSION}

The successful service organisation of the future will have to take the following important factors into account when it designs its services:

- It will have to become totally customer orientated

- Only highly skilled staff will come into contact with customers

- It will have to meet the challenges of a rapidly changing environment and will have to invest heavily in IT to take the advantage of the benefits e-commerce offers

- It will have to accept the reality that the provision of services will occur in different ways than in the past, and that the visible part of service provision will in many cases become more IT based

- It will have to develop leadership. Leadership, especially core value deployment will distinguish successful from unsuccessful organisations

- Customer retention strategies will have to be incorporated into service design

- Logistics, particularly those related to speedy delivery of products and services, will have to form an integral part of the delivery process.

Only those organisations that can cope with all these challenges will survive the demands of the new economic world. This will require a huge commitment from management and a shift in management thinking. Continuous awareness, quick adaptation to new circumstances and flexibility will be required from $21^{\text {st }}$ century managers. Those who cannot meet these demands will not survive.

\section{BIBLIOGRAPHY}

BATESON JEG. 1995. Managing Service Marketing. Orlando: Dryden.

BEELD. 2000. Persoonlike kontak moet bly ondanks groei in elektroniese media. Sakebeeld, 22 Junie:1.

HESKETT JL, JONES TO, LOVEMAN GW, SASSER WE \& SCHLESINGER LA. 1994. Putting the service profit chain to work. Harvard College.

LANGEARD E, BATESON J, LOVELOCK C \& EIGELIE P. 1981. Marketing of services: new perspectives from consumers and managers. Cambridge: Marketing Sciences Institute. 